\title{
Procollagen Type I Carboxy Terminal Peptide Measurement
}

National Cancer Institute

\section{Source}

National Cancer Institute. Procollagen Type I Carboxy Terminal Peptide Measurement. NCl Thesaurus. Code C82033.

The determination of the amount of procollagen type I carboxy terminal peptide present in a sample. 